\section{Yield and Fruit Quality Traits of Atemoya Hybrids Grown in Puerto Rico}

\author{
Ricardo Goenaga ${ }^{1}$ and David Jenkins
}

ADDITIONAL INDEX wORDs. tropical horticulture, tropical fruits, soluble solids concentration, Annona squamosa $\times$ A. cherimola

SUMMARY. As consumers seek healthy and more diverse food products, the demand for tropical fruits has increased significantly during the last 15 years. There is a lack of formal experimentation to determine the yield performance and fruit quality traits of atemoya (Annona squamosa $\times$ A. cherimola) hybrids. Six atemoya hybrids ('Bradley', 'Geffner', 'Priestly', 'Lisa', '47-18', and '75-9') grown on an Oxisol soil were evaluated for 4 years at Isabela, PR. 'Geffner' and 'Lisa' had the highest number of marketable fruit averaging 8542 fruit/ha, and the highest yield of marketable fruit, averaging $1507 \mathrm{~kg} \cdot \mathrm{ha}^{-1}$; they did not differ from each other, but were greater than all other hybrids. Individual weight of marketable fruit was significantly higher in '75-9' and 'Priestly' which averaged $264.8 \mathrm{~g}$. Significantly higher soluble solids concentration values were obtained from fruit of '75-9', 'Bradley', and 'Geffner' which averaged 23.8\%; they did not differ from each other, but were greater than all other hybrids.

A s consumers seek healthy and more diverse food products, the demand for tropical fruit has increased significantly during the last 15 years with an estimated value of production at $\$ 18$ billion in 2009 (Food and Agriculture Organization of the United Nations, 2011). Belonging to the Annonaceae family, the atemoya is an interspecific hybrid between the sugar apple (Annona squamosa) and the cherimoya (Annona cherimola) (Nakasone and Paull, 1998). The sugar apple is indigenous to the highlands of Peru and Ecuador, and the cherimoya is widely distributed throughout tropical South America (Marler et al., 1994). However, the term atemoya has also been used loosely in the literature for Annona hybrids resulting from 1) crosses between custard apple (atemoya $\times A$. reticulata), 2) cherimoya $\times A$. reticulata, and 3 ) for hybrids in which either A. squamosa or $A$. cherimola is used interchangeably as male or female parents. In this paper, we use the term "atemoya" as the collective term for all these Annona hybrids.

USDA-ARS, Tropical Agriculture Research Station, 2200 P.A. Campos Avenue, Suite 201, Mayaguez, Puerto Rico 00680-5470

We thank Angel Marrero, Pablo Rios, and Tomás Miranda for their excellent field assistance.

Mention of trade names or commercial products in this publication is solely for the purpose of providing specific information and does not imply recommendation or endorsement of the U.S. Department of Agriculture.

${ }^{1}$ Corresponding author. E-mail: ricardo.goenaga@ars. usda.gov.
The atemoya grows well in tropical and subtropical climates from sea level to an elevation of $\approx 1000 \mathrm{~m}$. It adapts to a wide range of soil types including sandy or heavy soils; however, it does not withstand waterlogged soils particularly when it is grafted onto sugar apple (Crane et al., 2013; Morton, 1987). In Florida orchards, atemoya budwood is usually grafted onto custard apple or sugar apple rootstocks; however, the most commonly used rootstock in Israel is the cherimoya (Campbell and Phillips, 1994; Morton, 1987).

Poor fruit set is the key obstacle for the cultivation of atemoya. The atemoya flowers exhibit protogynous dichogamy (female function precedes male function). This incompatibility problem results in incomplete pollination and the production of malformed fruit (Mossler and Crane, 2012). For this reason, hand pollination is often necessary to achieve profitable yields. Lack of pollinators also limits fruit set. Nitidulid beetles (Carpophilus sp. and Urophorus sp.) are the single most important pollinators of atemoya flowers and other annonaceous crops (Nadel and Peña, 1994). Fruit shape varies from conical to ovate; it has slight to pronounced surface protuberances, green-to greenishyellow skin and contains 10 to 40 dark brown to black seeds. Fruit pulp is white, smooth textured, sweet with a custard-like consistency (Campbell and Phillips, 1980; Crane et al., 2013). The fruit is high in dietary fiber and vitamin $\mathrm{C}$ and can range in weight from 200 to $900 \mathrm{~g}$ (Meadows and Oswald, 2012).

There is very little information available on total production area of atemoya worldwide. The largest producer in the United States is Florida, with annual production estimated at $50,000 \mathrm{lb}$ and an average seasonal price of $\approx \$ 4.00 / \mathrm{lb}$ (Mossler and Crane, 2012). In the United States, small orchards are known to have been established in Hawaii, CA, and Puerto Rico.

Commonly used hybrid cultivars for commercial production include Geffner, Page, African Pride, and Bradley (Crane et al., 2013). Production of fully matured trees of these hybrids is estimated to range from 75 to 200 fruit/year (Crane et al., 2013). However, results from long-term replicated field trials to evaluate these and other hybrids are very limited (Crane et al., 2013). The objective of this study is to evaluate the yield performance and fruit quality traits of six atemoya hybrids grown in an Oxisol typical of the humid tropics.

\section{Materials and methods}

This study was conducted in Puerto Rico at the U.S. Department of Agriculture, Agricultural Research Service Research Farm in Isabela

\begin{tabular}{llll}
\hline $\begin{array}{l}\text { Units } \\
\text { To convert U.S. to SI, } \\
\text { multiply by }\end{array}$ & U.S. unit & SI unit & $\begin{array}{l}\text { To convert SI to U.S., } \\
\text { multiply by }\end{array}$ \\
\hline 0.4047 & $\mathrm{acre}(\mathrm{s})$ & $\mathrm{ha}$ & $2.471 \mathrm{l}$ \\
0.3048 & $\mathrm{ft}$ & $\mathrm{m}$ & 3.2808 \\
3.7854 & $\mathrm{gal}$ & $\mathrm{L}$ & 0.2642 \\
2.54 & inch $(\mathrm{es})$ & $\mathrm{cm}$ & 0.3937 \\
25.4 & inch $(\mathrm{es})$ & $\mathrm{mm}$ & 0.0394 \\
0.4536 & $\mathrm{lb}$ & $\mathrm{kg}$ & 2.2046 \\
1.1209 & $\mathrm{lb} / \mathrm{acre}$ & $\mathrm{kg} \cdot \mathrm{ha}^{-1}$ & 0.8922 \\
28.3495 & $\mathrm{oz}$ & $\mathrm{g}$ & 0.0353 \\
1 & $\mathrm{ppm}$ & $\mathrm{mg} \cdot \mathrm{kg}^{-1}$ & 1 \\
6.8948 & $\mathrm{psi}$ & $\mathrm{kPa}$ & 0.1450 \\
$\left({ }^{\circ} \mathrm{F}-32\right) \div 1.8$ & ${ }^{\circ} \mathrm{F}$ & ${ }^{\circ} \mathrm{C}$ & $\left({ }^{\circ} \mathrm{C} \times 1.8\right)+32$ \\
& & &
\end{tabular}


(Coto clay: clayey, kaolinitic isohyperthermic Typic Hapludox). The soil has a $\mathrm{pH}$ of $5.68,154 \mathrm{mg} \cdot \mathrm{kg}^{-1}$ ammoniumnitrogen $\left(\mathrm{NH}_{4}-\mathrm{N}\right), 6.2 \mathrm{mg} \cdot \mathrm{kg}^{-1}$ nitrate-nitrogen $\left(\mathrm{NO}_{3}-\mathrm{N}\right), 5.8 \mathrm{mg} \cdot \mathrm{kg}^{-1}$ phosphorous $(\mathrm{P}), 63.5 \mathrm{mg} \cdot \mathrm{kg}^{-1}$ potassium (K), $1192 \mathrm{mg} \cdot \mathrm{kg}^{-1}$ calcium (Ca), $93 \mathrm{mg} \cdot \mathrm{kg}^{-1}$ magnesium $(\mathrm{Mg})$, $39 \mathrm{mg} \cdot \mathrm{kg}^{-1}$ iron $(\mathrm{Fe}), 245 \mathrm{mg} \cdot \mathrm{kg}^{-1}$ manganese $(\mathrm{Mn}), 2.80 \mathrm{mg} \cdot \mathrm{kg}^{-1}$ zinc $(\mathrm{Zn})$, and $1.42 \%$ organic carbon. The 95-year (1919-2014) mean annual rainfall is $1649 \mathrm{~mm}$ and Class A pan evaporation is $1672 \mathrm{~mm}$. Mean monthly maximum and minimum temperatures are 29.8 and $19.9^{\circ} \mathrm{C}$. Soil samples were taken 2 months before planting by taking 15 borings at a depth of 0-10 inches from each of the projected hybrid rows. Samples were air-dried and passed through a 20 -mesh screen. Soil $\mathrm{pH}$ in water and $0.01 \mathrm{M}$ calcium chloride (1 soil : 2 water) were measured with a glass electrode. Exchangeable cations (potassium, magnesium, and calcium) were extracted with neutral $1 \mathrm{~N}$ ammonium acetate and determined by atomic absorption spectroscopy (Sumner and Miller, 2007). Phosphorus was extracted with $1 \mathrm{~N}$ ammonium fluoride and $0.5 \mathrm{~N}$ hydrochloric acid and determined using the ascorbic acid method (Benton, 2001). Organic carbon was determined by the WalkleyBlack method (Nelson and Sommers,
2007). Soil ammonium and nitrate were determined by steam distillation (Mulvaney, 2007). Originally, the experiment was also established at a second location in a clayey, mixed, isohyperthermic Aquic Haplohumults Ultisol soil. However, a combination of this site having a very heavy, clayey soil and a prolonged wet period due to heavy rainfall caused high mortality among plants forcing us to end research at this site.

Six-month-old trees of hybrids 'Bradley', 'Geffner', 'Priestly', 'Lisa', '47-18', and '75-9' grafted onto 'Lessard Thai' sugar apple rootstock were transplanted to the field on 8 Aug. 2001 and were arranged in a randomized complete block design with four replications. 'Bradley' is one of the first named selections of atemoya. 'Geffner' and 'Priestly' are Israeli selections (Morton, 1987). 'Lisa' is 'Libby' cherimoya $\times$ 'Red Sugar' sugar apple, '47-18' and '759 ' originated from controlled pollination crosses of 'Geffner' atemoya $\times$ 'San Pablo' A. reticulata, and 'Spain' cherimoya $\times$ 'Felipe Canul' $A$. reticulata, respectively. All plant material was obtained from Zill's High Performance Plants (Boynton Beach, FL) and shipped air freight to Puerto Rico. 'Lisa', '47-18', and '75-9' are atemoya hybrids developed in that nursery by Mr. Gary Zill and have shown commercial potential in nonreplicated plots at the nursery. Before transplanting, the soil was chisel plowed to a depth of $90 \mathrm{~cm}$. Planting holes of 1.5-ft depth were dug with an auger connected by a drive shaft to the power-take-off unit of a tractor. On transplanting day, each grafted tree received $11 \mathrm{~g}$ granular $\mathrm{P}$ provided in the form of triple superphosphate. Within a replication, plots for each hybrid contained two trees spaced $4 \mathrm{~m}$ apart and $6 \mathrm{~m}$ between adjacent rows in a triangular array, 168 trees/ acre. As an effort to identify hybrids not needing artificial pollination, hand pollination was not performed in this study. This experiment was surrounded by two guard rows of custard apple seedlings.

Irrigation based on tensiometer readings was provided through drip irrigation with two 2 -gal/h emitters per tree spaced $1.8 \mathrm{~m}$ apart when the soil water tension at a depth of 12 inches exceeded $50 \mathrm{kPa}$. Fertilization was provided every 3 months using a $15 \mathrm{~N}-2.2 \mathrm{P}-16.3 \mathrm{~K}-1.8 \mathrm{Mg}$ fertilizer at a rate of $185 \mathrm{lb} /$ acre. Herbicide (glyphosate) for weed control was applied only in strips within the planting row. Weeds between rows were controlled with a tractor mower.

Harvests were initiated in Jan. 2006. At this time, experimental trees were 6 years old and producing fruit

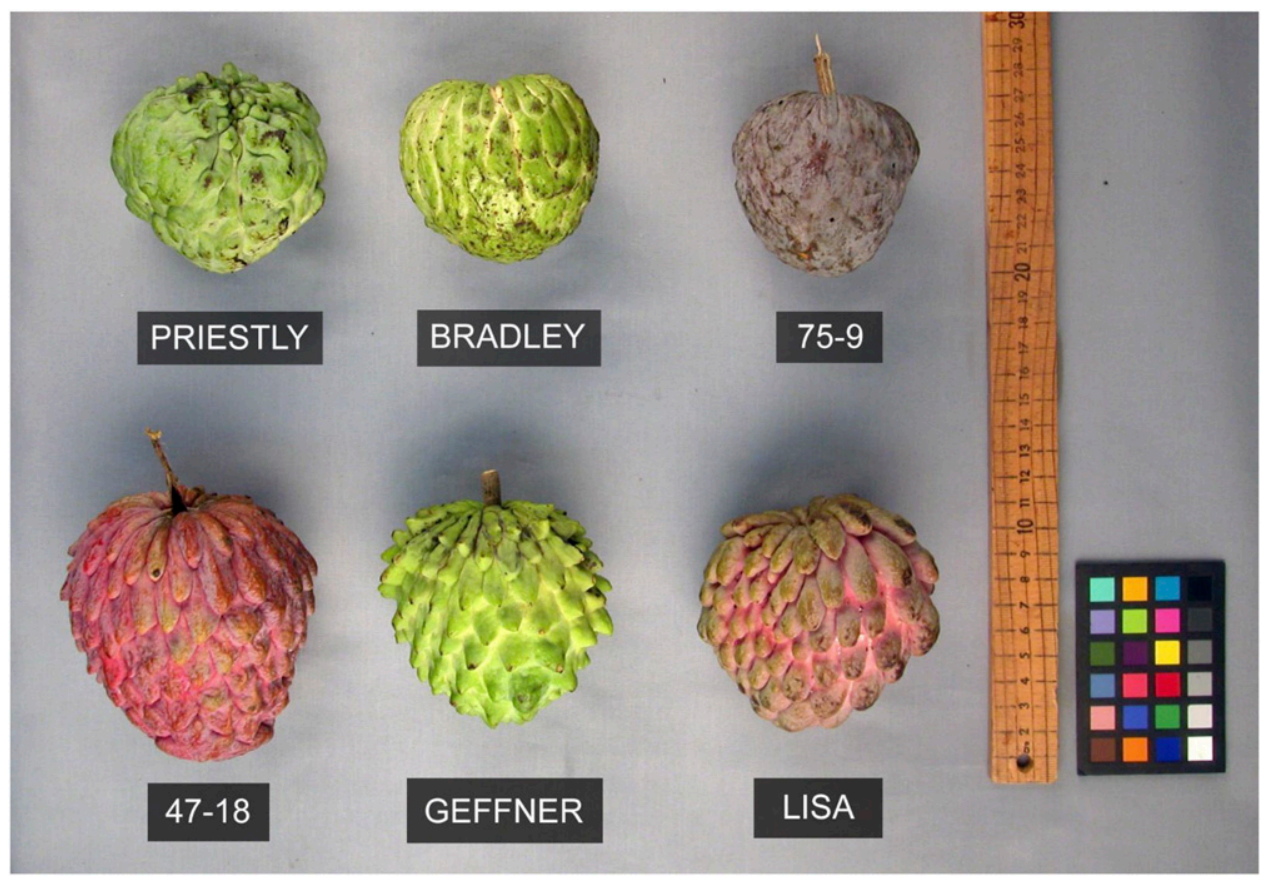

Fig. 1. Representative fruit of six atemoya hybrids grown in Puerto Rico. 
in sufficiently large numbers for commercial harvest and sale. At each harvest, number and weight of marketable and nonmarketable fruit were recorded. Deformed fruit and those weighing less than $150 \mathrm{~g}$ were considered nonmarketable. Representative fruit from each hybrid is shown in Fig. 1. Fruit totaling 10\% of those harvested were used to determine total soluble solids using a temperature-compensated digital refractometer (Pal-1; Atago, Tokyo, Japan) when the fruit ripened at room temperature $\left(\approx 75^{\circ} \mathrm{F}\right), \approx 5 \mathrm{~d}$ after harvest. After a 4-year harvesting period, the experiment was ended in Dec. 2009.

Analysis of variance was carried out using the GLM procedure of SAS (version 9.1 for Windows; SAS Institute, Cary, NC). After significant $\mathrm{F}$ test at $P=0.05$, means separation was performed using Tukey's Studentized range test.

\section{Results and discussion}

Year, hybrids, and the year $\times$ hybrid interaction showed highly significant effects $(P \leq 0.01)$ on all fruit parameters measured in the study (Table 1). The only exception was total soluble solids, which did not show a significant year effect.

As expected, all hybrids exhibited an overall increase in the number and yield of marketable fruit as trees increased in age (Table 2). However, the magnitude of this response varied among hybrids as expected by the significant year $\times$ hybrid interaction (Table 1). Years of heavy cropping were followed by lower production and yield of marketable fruit the following year for particular hybrids (Table 2). Most probably, the high fruit load in some cultivars resulted in depletion of assimilates, which then caused an "off-year" because of light blooming as trees built up carbohydrate reserves (Scholefield et al., 1985). This was particularly the case for 'Geffner' in 2007-08 and 'Lisa' and '75-9' in 2008-09 (Table 2). 'Bradley' was the only hybrid showing relatively stable marketable fruit production and yield. The fact that it did not have a year of heavy cropping supports the hypothesis of assimilate depletion in other hybrids.

'Geffner' and 'Lisa' had the highest 4-year mean for number and yield of marketable fruit with values being significantly higher than for all

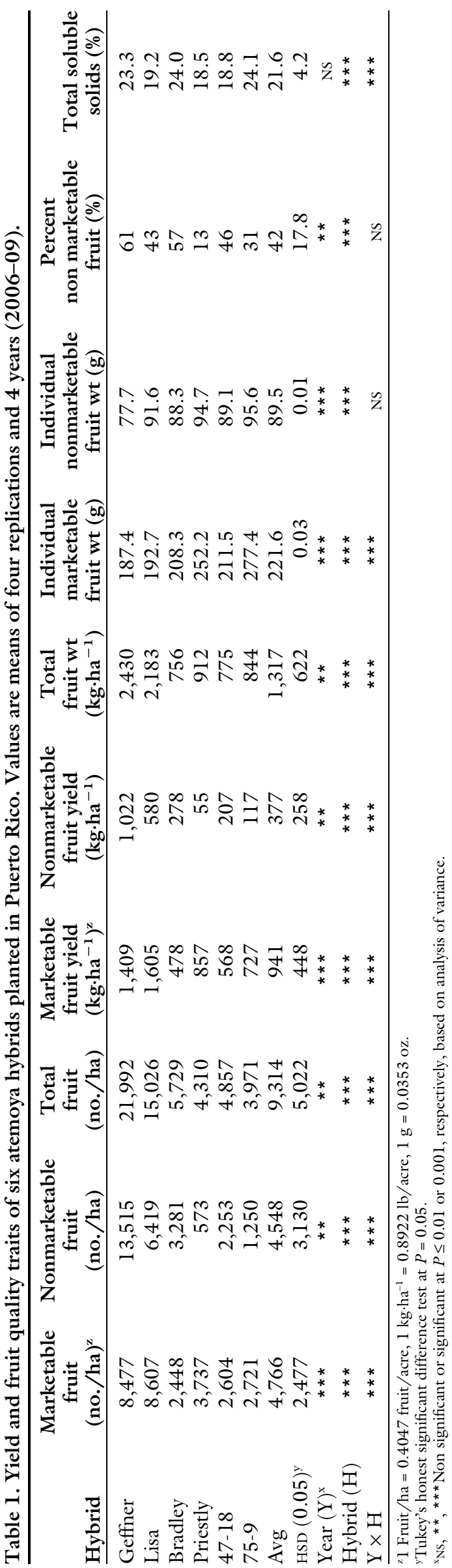


Table 2. Number and yield of marketable fruit of six hybrids of atemoya grown in Puerto Rico. Values are means of four replications.

\begin{tabular}{|c|c|c|c|c|c|c|c|c|c|c|}
\hline \multirow[b]{2}{*}{ Hybrid } & \multicolumn{5}{|c|}{ Marketable fruit (no./ha $)^{\mathrm{z}}$} & \multicolumn{5}{|c|}{ Marketable wt $\left(\mathrm{kg} \cdot \mathrm{ha}^{-1}\right)^{\mathrm{z}}$} \\
\hline & $4 \mathrm{yr}$ & 2006 & 2007 & 2008 & 2009 & $4 \mathrm{yr}$ & 2006 & 2007 & 2008 & 2009 \\
\hline Geffner & 8,477 & 1,875 & 13,125 & 7,760 & 11,146 & 1,409 & 440 & 1,951 & 1,487 & 1,757 \\
\hline Bradley & 2,448 & 1,823 & 2,448 & 2,552 & 2,969 & 478 & 500 & 368 & 512 & 533 \\
\hline Priestly & 3,737 & 52 & 2,448 & 4,167 & 8,281 & 857 & 27 & 482 & 1,158 & 1,760 \\
\hline $47-18$ & 2,604 & 1,302 & 2,500 & 5,312 & 1,302 & 568 & 338 & 475 & 1,189 & 272 \\
\hline $\operatorname{HSD}(0.05)^{\mathrm{y}}$ & 2,477 & 2,413 & 5,330 & 5,752 & 7,232 & 448 & 665 & 940 & 1,110 & 1,163 \\
\hline
\end{tabular}

${ }^{\mathrm{z}} 1$ Fruit/ha $=0.4047$ fruit/acre; $1 \mathrm{~kg} \cdot \mathrm{ha}^{-1}=0.8922 \mathrm{lb} /$ acre.

yTukey's honest significant difference test at $P=0.05$.

other hybrids (Table 2). These two hybrids had the highest number of marketable fruit in 2 of the 4 years the experiment lasted. However, 'Bradley' had the lowest 4-year mean for number of marketable fruit and marketable yield although values for this hybrid were not significantly different from for 'Priestly', '47-18', and '759' (Table 2).

Total number of fruit was significantly different among hybrids (Table 1). 'Geffner' and 'Lisa' produced a significantly higher number of total fruit; they did not differ from each other, but were greater than all other hybrids. There was no statistically significant difference in the number of total fruit produced by 'Bradley', '47-18', 'Priestly', and '75-9' (Table 1). There were no significant differences in marketable fruit production between 'Geffner' and 'Lisa' which averaged 8542 fruit/ha. Their production of marketable fruit was significantly higher than those of all other hybrids, which averaged 2877 fruit/ha (Table 1). As a percentage of total fruit production, hybrid cultivars Geffner, Bradley, 47-18, and Lisa produced a significantly higher percentage of nonmarketable fruit averaging $52 \%$ (Table 1 ).

Significantly higher yield of marketable fruit was obtained by 'Geffner' and 'Lisa' in comparison with all other hybrids; these yields did not differ between these cultivars, averaging $1507 \mathrm{~kg} \cdot \mathrm{ha}^{-1}$ (Table l). There were no significant differences in marketable fruit yield among 'Bradley', 'Priestly', '47-18', and '75-9', averaging only $657 \mathrm{~kg} \cdot \mathrm{ha}^{-1}$. In spite of 'Geffner' producing a significantly higher number of total fruit than other hybrids, this did not translate in a concomitant significant increase in fruit yield. For example, 'Geffner' produced over $30 \%$ more fruit than 'Lisa' but there were no significant differences in yield of marketable fruit between these two hybrids (Table 1). The larger number of fruit produced by 'Geffner' may have resulted in high sink demand and smaller fruit.

Fewer fruit and lower fruit yield by 'Bradley', 'Priestly', '47-18', and '75-9' may have been the result of protogyny (Crane et al., 2013; Mossler and Crane, 2012) or lack of natural pollinators (Crane et al., 2013). There has been some success using nitidulid pheromones to attract pollinators into atemoya orchards, thereby increasing fruit set (Nadal and Peña, 1994; Peña et al., 1999). Preliminary work by the authors indicates that these commercially available pheromones attract nitidulid species responsible for pollination in atemoya (Jenkins et al., 2013, 2015).

Individual weight of marketable fruit averaged over hybrids was $221.6 \mathrm{~g}$ (Table 1). It is noteworthy that the individual weight of marketable fruit in 'Geffner' (187.4 g) was significantly lower than those for other cultivars supporting the hypothesis that the large number of fruit produced by this hybrid resulted in smaller fruit. Individual weight of marketable fruit was significantly higher in '75-9' and 'Priestly' with fruit weight values of 277.4 and $252.2 \mathrm{~g}$, respectively. These weights were significantly different from each other and greater than that obtained for all the other hybrids. Individual weight of nonmarketable fruit was significantly higher (95.6 g) in '759' and lower (77.7 g) in 'Geffner' (Table 1).
Significantly higher soluble solids concentration values were obtained from fruit of ' $75-9$ ' and 'Bradley' which averaged $24.0 \%$ (Table 1 ). These values are similar to those obtained by others (Chiang and Liu, 2011; Paull, 1996).

In conclusion, six atemoya hybrids were evaluated for the first time during 4 years of production. Hybrid cultivars Geffner and Lisa produced more marketable fruit and had higher marketable fruit yield than the rest of the hybrids used in this study.

\section{Literature cited}

Benton, J.J. 2001. Laboratory guide for conducting soil tests and plant analysis. CRC Press, Boca Raton, FL.

Campbell, C.W. and R.L. Phillips. 1980. The atemoya. Univ. Florida, Florida Coop. Ext. Serv., Inst. Food Agr. Sci., Fruit Crops Fact Sheet FC-64.

Campbell, C.W. and R.L. Phillips. 1994. The atemoya. Univ. Florida, Florida Coop. Ext. Serv., Inst. Food Agr. Sci., Fact Sheet HS-64.

Chiang, S.W. and P.S. Lu. 2011. Characteristics of growth and development of atemoya fruits in Taitung, Taiwan. J. Taiwan Soc. Hort. Sci. 57:9-17.

Crane, J.H., C.F. Balerdi, and I. Maguire. 2013. Atemoya growing in the Florida home landscape. Univ. Florida, Florida Coop. Ext. Serv., Inst. Food Agr. Sci., Fact Sheet HS-64.

Food and Agriculture Organization of the United Nations. 2011. Intergovernmental Group on Bananas and Tropical Fruits. Committee on Commodity Problems. Current situation and short-term outlook. 5th session. Yaoundé, Cameroon. 8 Mar. 2016. <http://www.fao.org/ docrep/meeting/028/ma937e.pdf $>$. 
Jenkins, D.A., A.R. Cline, B. Irish, and R. Goenaga. 2013. Attraction of pollinators to atemoya (Magnoliales: Annonaceae) in Puerto Rico: A synergistic approach using multiple nitidulid lures. J. Econ. Entomol. 106:305-310.

Jenkins, D.A., C. Millan-Hernandez, A.R. Cline, T.C. McElrath, B. Irish, and R. Goenaga. 2015. Attraction of pollinators to atemoya (Annona squamosalx Annona cherimola) in Puerto Rico using commercial lures and food attractants. J. Econ. Entomol. 108:1923-1929.

Marler, T.E., A.P. George, R.J. Missen, and P.C. Andersen. 1994. Miscellaneous tropical fruits, p. 200-205. In: B. Schaffer and P.C. Andersen (eds.). Handbook of environmental physiology of fruit crops: II. Subtropical and tropical crops. CRC Press, Boca Raton, FL.

Morton, J.F. 1987. Fruits of warm climates. Media Inc., Greensboro, NC.

Meadows, J. and M.J. Oswald. 2012. Atemoya. 1 Feb. 2016 . <http://
sarasota.ifas.ufl.edu/fcs/FlaFoodFare/ Atemoya.pdf $>$.

Mossler, M.A. and J. Crane. 2012. Florida crop/pest management profile: Atemoya and sugar apple. Univ. Florida, Florida Coop. Ext. Serv., Inst. Food Agr. Sci., Document CIR 1417.

Mulvaney, R.L. 2007. Nitrogen: Inorganic forms, p. 1123-1184. In: D.L. Sparks (ed.). Methods of soil analysis. Part 3. Chemical methods. Soil Sci. Soc. Amer., Amer. Soc. Agron., Madison, WI.

Nadel, H. and J.E. Peña. 1994. Identity, behavior, and efficacy of nitidulid beetles (Coleoptera: Nitidulidae) pollinating commercial Annona species in Florida. Environ. Entomol. 23:878-886.

Nakasone, H.Y. and R.E. Paull. 1998. Tropical Fruits. CAB Intl., Wellingford, UK.

Nelson, D.W. and L.E. Sommers. 2007. Total carbon, organic carbon and organic matter, p. 961-1010. In: D.L. Sparks (ed.). Methods of soil analysis. Part 3. Chemical methods. Soil Sci. Soc. Amer., Amer. Soc. Agron., Madison, WI.

Paull, R.E. 1996. Postharvest atemoya fruit splitting during ripening. Postharvest Biol. Technol. 8:329-334.

Peña, J.E., A. Castiñeiras, R. Bartelt, and R. Duncan. 1999. Effect of pheromone bait stations for sap beetles (Coleoptera: Nitidulidae) on Annona spp. fruit set. Fla. Entomol. 82:475-480.

Scholefield, P.B., M. Sedgley, and D. McE. Alexander. 1985. Carbohydrate cycling in relation to shoot growth, floral initiation and development and yield in the avocado. Sci. Hort. 25:99-110.

Sumner, M.E. and W.P. Miller. 2007. Cation exchange capacity and exchange coefficients, p. 1201-1230. In: D.L. Sparks (ed.). Methods of soil analysis. Part 3. Chemical methods. Soil Sci. Soc. Amer., Amer. Soc. Agron., Madison, WI. 